\title{
21. GEOCHEMICAL ANALYSIS OF SAMPLES FROM SITES 397 AND 398
}

\author{
Daniel B. Pearson, The Superior Oil Company, Houston, Texas \\ and \\ Wallace G. Dow, Getty Oil Company, Houston, Texas ${ }^{1}$
}

\section{INTRODUCTION}

Economic interest in the Atlantic continental margins makes geochemical evaluation of the Cretaceous black shale sequence on both sides of the Atlantic especially timely. Cretaceous black shale has been encountered in several DSDP core holes on both sides of the North Atlantic, but it has always been too immature to demonstrate any significant degree of oil generation. Samples from Sites 397 and 398 of Leg 47 (Figure 1) offer an opportunity to study the Cretaceous black shale on the eastern side of the Atlantic in detail, to evaluate its petroleum-generating capability, and to allow comparison of the black shale geology on the opposite sides of the Atlantic. Toward this goal, 23 core samples were selected for geochemical and maturity analysis.

\section{EXPERIMENTAL PROCEDURES}

The sample preparation procedure for the analyses of Leg 47 sample suites is similar to that of Leg 44 (Dow, 1978a, b).

\section{RESULTS}

\section{Site 397}

Medium greenish gray shales of early Miocene age are rated as good to very good potential sources for oil and wet gas. Medium to dark gray shales of Early Cretaceous (Hauterivian) age are rated good potential wet gas sources. The kerogen in the lower Miocene section is comprised primarily of amorphous, oil-type organic matter with secondary amounts of humic organic matter. The amount and type of kerogen present in the samples suggest that oil and wet gas could be generated under appropriate time-temperature conditions. The lower organic carbon content and more humic nature of the kerogen in the Lower Cretaceous sample suggest that it could generate only limited amounts of predominantly wet gas. The top of the oil-generation maturity zone $\left(0.6 \% \mathrm{R}_{\mathrm{o}}\right)$ is projected at approximately 1870 meters sub-bottom; the top of significant wet gas generation $\left(0.8 \% \mathrm{R}_{\mathrm{o}}\right)$ is projected at approximately 2310 meters sub-bottom. Maturity analysis suggests also that approximately 250 meters of section has been lost

'Present address: U.S. Geological Survey, Denver Federal Center, Denver, Colorado.

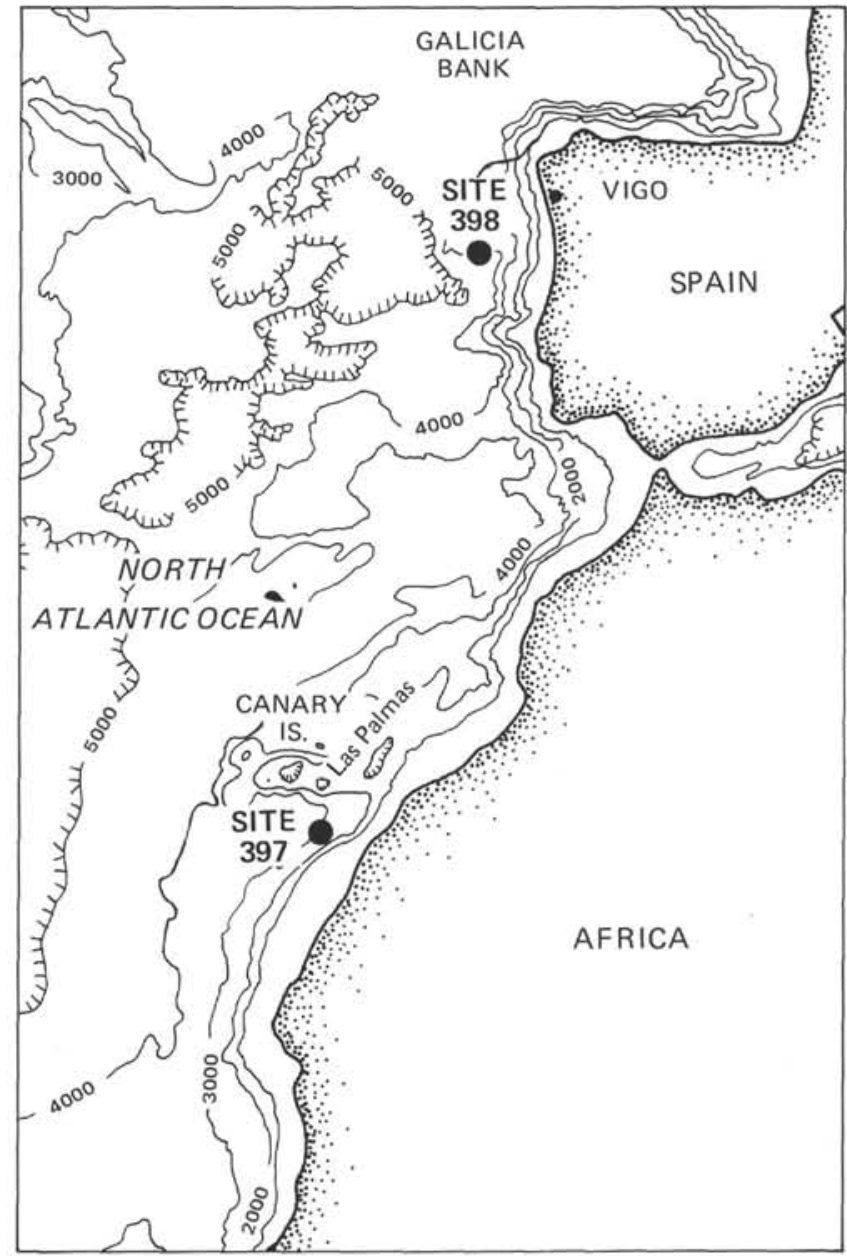

Figure 1. Leg 47 drill sites.

to erosion at the Early Cretaceous-early Miocene unconformity.

Site 398

Finely laminated light greenish to brownish gray siltstones and shales of Miocene and Eocene age are rated as nonsource rocks due to very low organic carbon contents. The kerogen in these samples is predominantly humic. The organic content of the Cretaceous samples is variable, but all rate from marginal to good in source quality. High relative amounts of amorphous oilgenerating kerogen is present in some samples of Albian age. The top of the oil generation maturity zone $(0.6 \%$ 
$R_{O}$ ) is estimated to be approximately 2150 meters subbottom; the beginning of significant wet gas generation $\left(0.8 \% \mathrm{R}_{\mathrm{O}}\right)$ is estimated to be approximately 2770 meters sub-bottom. Thus, the entire sampled section is of preoil-generation maturity. Maturation analysis also indicates that about $\mathbf{3 2 0}$ meters of section was lost to erosion at the Campanian-Cenomanian unconformity. PreCampanian rocks have three populations of recycled humic organic matter which were deposited as particles of lignite, high volatile " $\mathrm{B}$ " and " $\mathrm{A}$ " bituminous coal. If the predominantly terrestrial and recycled organic matter in the pre-Albian shales is representative of preAlbian source rocks, there appears to be little likelihood of any oil being generated even with additional burial. The more amorphous-rich Albian, with additional burial, might generate oil.

\section{Site 397}

\section{DISCUSSION}

\section{Organic Carbon and Carbonate Content}

Organic carbon content (Table 1) is variable in the medium greenish gray lower Miocene shales, ranging from 1.29 to 2.03 weight per cent. The medium to dark gray lower Cretaceous shale is lower in organic carbon despite its darker color. The Tertiary samples are fairly uniform in carbonate content (Table 1), averaging 30 per cent by weight; the Cretaceous sample is $<10$ per cent by weight carbonate. Based on their organic carbon contents, the Miocene samples are rated as good to very good in source quality and the Cretaceous sample is rated good. The analyzed samples may not be representative of the penetrated section because only the darkest, supposedly most organic-rich samples were selected for analysis.

\section{Organic Extract}

Extractable organic matter data are summarized on Tables 2 and 3 , and a gas chromatogram of the total saturate fraction of the lower Cretaceous sample is shown on Figure 2. The extract to organic carbon ratios (Table 3 ) for the Tertiary and Cretaceous samples are extremely low, generally less than 0.01 , indicating essentially no generation of soluble organics. Extract from the Cretaceous sample (Table 2) is moderately high in saturates possibly indicating generation of petroleumlike components. The high NSO content, however, suggests immaturity as does the very high odd carbon predominance (CPI) in the saturate fraction. The high saturate content could be due to contamination of this sample by drilling associated lubricants as suggested by Dow (1978b) for certain Leg 44 sample extracts.

\section{Kerogen Type}

All of the kerogen in the samples are mixed maceral types. The Tertiary samples contain predominantly amorphous marine organic matter with secondary amounts of terrestrial humic kerogen. The Cretaceous sample contains predominantly humic organic matter with lesser amounts of amorphous kerogen (Table 3 ). Based on the type of organic matter present, the Tertiary is judged to be capable of generating oil and wet

TABLE 1

Organic Carbon Data

\begin{tabular}{|c|c|c|c|c|}
\hline $\begin{array}{c}\text { Sample } \\
\text { (Interval in } \mathrm{cm} \text { ) }\end{array}$ & Age & Lithology & $\begin{array}{c}\text { HCL Sol. } \\
\text { (wt. \%) }\end{array}$ & $\begin{array}{l}\text { Org. Carb. } \\
\text { (wt. \%) }\end{array}$ \\
\hline \multicolumn{5}{|l|}{ Leg 49A } \\
\hline $\begin{array}{l}397-95-4,125-135 \\
397 \mathrm{~A}-12-2,0-20 \\
397 \mathrm{~A}-16-4,25-30 \\
\text { 397A-23-4, 10-20 } \\
\text { 397A-51-4, } 135-140\end{array}$ & $\begin{array}{l}\text { Early Miocene } \\
\text { Early Miocene } \\
\text { Early Miocene } \\
\text { Early Miocene } \\
\text { Hauterivian }\end{array}$ & $\begin{array}{l}\text { Medium brownish gray shale } \\
\text { Medium greenish gray shale } \\
\text { Medium greenish gray shale } \\
\text { Medium greenish gray shales } \\
\text { Medium dark gray shales }\end{array}$ & $\begin{array}{r}-\overline{27.1} \\
30.7 \\
34.7 \\
8.5\end{array}$ & $\begin{array}{l}1.33 \\
2.03 \\
1.29 \\
0.99\end{array}$ \\
\hline \multicolumn{5}{|l|}{ Leg 47B } \\
\hline $\begin{array}{l}398 \mathrm{D}-12-3,120-135 \\
398 \mathrm{D}-19-3,130-137 \\
\text { 398D-27-2, 130-140 } \\
\text { 398D-62-4, } 120-130 \\
\text { 398D-65-4, } 0-110\end{array}$ & $\begin{array}{l}\text { Early Miocene } \\
\text { Late Eocene } \\
\text { Middle Eocene } \\
\text { Albian } \\
\text { Albian }\end{array}$ & $\begin{array}{l}\text { Finely laminated, light green-gray mudstone } \\
\text { Light gray-brown laminated mudstone } \\
\text { Laminated light green-gray shale white laminated } \\
\text { Finely laminated medium dark gray-black shale } \\
\text { Medium green-gray shale }\end{array}$ & $\begin{array}{l}36.4 \\
32.9 \\
40.2 \\
41.1 \\
37.4\end{array}$ & $\begin{array}{l}0.11 \\
0.06 \\
0.08 \\
0.52 \\
0.34\end{array}$ \\
\hline $\begin{array}{l}\text { 398D-69-2, 103-106 } \\
\text { 398D-73-4, 140-145 } \\
\text { 398D-77-4, 100-108 } \\
\text { 398D-80-2, 100-110 } \\
\text { 398D-86-4, 50-56 }\end{array}$ & $\begin{array}{l}\text { Albian } \\
\text { Albian } \\
\text { Albian } \\
\text { Albian } \\
\text { Albian }\end{array}$ & $\begin{array}{l}\text { Dark green-gray shale } \\
\text { Dark gray-black shale } \\
\text { Black shale } \\
\text { Dark green-gray shale } \\
\text { Dark gray-black finely laminated shale }\end{array}$ & $\begin{array}{l}9.6 \\
5.0 \\
4.0 \\
3.2 \\
9.4\end{array}$ & $\begin{array}{l}0.73 \\
0.71 \\
0.74 \\
0.54 \\
1.67\end{array}$ \\
\hline $\begin{array}{l}398 \mathrm{D}-90-5,30-40 \\
398 \mathrm{D}-97-3,34-50 \\
398 \mathrm{D}-103-4,40-50 \\
398 \mathrm{D}-106-5,140-150 \\
398 \mathrm{D}-112-2,25-50\end{array}$ & $\begin{array}{l}\text { Albian } \\
\text { Albian } \\
\text { Albian } \\
\text { Aptian } \\
\text { Aptian }\end{array}$ & $\begin{array}{l}\text { Black shale } \\
\text { Black shale } \\
\text { Dark green-gray shale } \\
\text { Medium green-gray shale } \\
\text { Medium green-gray shale }\end{array}$ & $\begin{array}{l}3.4 \\
3.9 \\
3.8 \\
9.1 \\
6.3\end{array}$ & $\begin{array}{l}1.05 \\
1.56 \\
0.84 \\
0.61 \\
0.45\end{array}$ \\
\hline $\begin{array}{l}398 \mathrm{D}-118-5,30-50 \\
398 \mathrm{D}-122-5,114-118 \\
398 \mathrm{D}-130-5,113-118\end{array}$ & $\begin{array}{l}\text { Aptian } \\
\text { Aptian } \\
\text { Barremian }\end{array}$ & $\begin{array}{l}\text { Medium dark gray, finely laminated shale } \\
\text { Medium dark gray finely laminated shale } \\
\text { Medium dark gray finely laminated shale }\end{array}$ & $\begin{array}{r}5.1 \\
22.9 \\
42.1\end{array}$ & $\begin{array}{l}0.87 \\
1.78 \\
0.97\end{array}$ \\
\hline
\end{tabular}


TABLE 2

Soxhlet Extraction Data

\begin{tabular}{lccrrr}
\hline \multirow{2}{*}{$\begin{array}{c}\text { Sample } \\
\text { (Interval in cm) }\end{array}$} & $\begin{array}{c}\text { Total Extract } \\
\text { Soxhlet (ppm) }\end{array}$ & \multicolumn{5}{c}{ Per Cent Composition } \\
\cline { 5 - 7 } & & Sat. & Arom. & NSO & Asph. \\
\hline \multicolumn{1}{c}{ Leg 47A } & & & & & \\
397A-51-4, 135-140 & 1,679 & 43.0 & 7.3 & 37.8 & 11.9 \\
\hline \multicolumn{1}{c}{ Leg 47B } & & & & & \\
398D-62-4, 120-130 & 1,828 & 17.0 & 6.4 & 54.3 & 22.3 \\
398D-69-2, 103-106 & 1,088 & 19.1 & 7.3 & 51.8 & 21.8 \\
398D-77-4, 100-108 & 799 & 27.7 & 5.3 & 60.6 & 6.4 \\
398D-90-5, 30-40 & 1,000 & 14.2 & 11.5 & 63.7 & 10.6 \\
398D-1 03-4, 40-50 & 1,082 & 22.1 & 12.8 & 54.7 & 10.5 \\
398D-1 18-5, 30-50 & 1,958 & 15.2 & 14.2 & 50.0 & 20.8 \\
398D-1 30-5, 113-118 & 921 & 14.4 & 7.2 & 68.0 & 10.3 \\
\hline
\end{tabular}

gas, and the Cretaceous sample might generate wet and dry gas (Table 3). Amorphous sapropelic kerogen is relatively rich in hydrogen and is capable of yielding predominantly oil under appropriate thermal and exposure time conditions (maturation). Humic organic matter is much lower in hydrogen and can generate only small amounts of gas with maturation (Dow, 1977). Oil source rocks typically have lower CPIs and higher extract to organic carbon ratios than gas source rocks at similar maturities. The potential generation product for each sample is shown in Table 3.

\section{Kerogen Maturity}

Maturity of the samples as determined by vitrinite reflectance, $R_{O}$ average (see Dow, 1977, 1978a, b), is shown on Table 4. The maturation profile for Site 397 (Figure 3) indicates that the samples are immature, all being less than the minimum maturity for significant oil

TABLE 3

Source Rock Data

\begin{tabular}{|c|c|c|c|c|}
\hline \multirow{2}{*}{$\begin{array}{c}\text { Sample } \\
\text { (Interval in } \mathrm{cm} \text { ) }\end{array}$} & \multirow{2}{*}{ 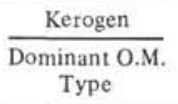 } & \multicolumn{2}{|c|}{ Extract } & \multirow{2}{*}{$\begin{array}{l}\text { Source } \\
\text { Type }\end{array}$} \\
\hline & & CPI & Ext./O.C. & \\
\hline \multicolumn{5}{|l|}{ Leg 47A } \\
\hline $397-95-4,125-135$ & Amorphous & - & - & - \\
\hline $397 \mathrm{~A}-12-2,0-20$ & Amorphous & - & 0.003 & Oil \\
\hline $397 \mathrm{~A}-16-4,25-30$ & Amorphous & - & 0.002 & Oil and wet gas \\
\hline $397 \mathrm{~A}-23-4,10-20$ & Amorphous & - & 0.010 & Oil \\
\hline $397 \mathrm{~A}-51-4,135-140$ & Humic & 4.43 & 0.004 & Wet and dry gas \\
\hline \multicolumn{5}{|l|}{ Leg 47B } \\
\hline $398 \mathrm{D}-12-3,120-135$ & Humic & - & 0.040 & Gas \\
\hline $398 \mathrm{D}-19-3,130-137$ & Humic & - & 0.024 & Gas \\
\hline $398 D-27-2,130-140$ & Humic & - & 0.002 & Wet gas and oil \\
\hline $398 D-62-4,120-130$ & Amorphous & 1.27 & 0.004 & Oil \\
\hline 398 D- $65-4,100-110$ & Amorphous & - & 0.018 & Oil \\
\hline $398 D-69-2,103-106$ & Amorphous & 1.36 & 0.003 & Oil \\
\hline $398 D-73-4,140-145$ & Amorphous & - & 0.002 & Oil \\
\hline $398 D-77-4,100-108$ & Amorphous & 1.57 & 0.002 & Oil \\
\hline $398 D-80-2,100-110$ & Amorphous & - & 0.002 & Oil and wet gas \\
\hline $398 D-86-4,50-56$ & Humic & - & 0.002 & Wet gas and oil \\
\hline $398 D-90-5,30-40$ & Humic & 1.51 & 0.005 & Wet gas and oil \\
\hline $398 \mathrm{D}-97-3,34-50$ & Humic & - & 0.003 & Wet gas and oil \\
\hline $398 \mathrm{D}-103-5,40-50$ & Humic & 1.41 & 0.001 & Wet and dry gas \\
\hline $398 D-106-5,140-150$ & Humic & - & 0.002 & Dry gas \\
\hline $398 \mathrm{D}-112-2,25-50$ & Humic & - & 0.019 & Dry gas \\
\hline $398 \mathrm{D}-118-5,30-50$ & Humic & 3.47 & 0.011 & Dry gas \\
\hline $398 D-122-5,114-118$ & Humic & - & 0.002 & Dry gas \\
\hline $398 D-130-5,113-118$ & Humic & 1.33 & 0.003 & Dry gas \\
\hline
\end{tabular}

generation $\left(0.6 \% R_{0}\right)$, as indicated in Figure 4 . Thus, the entire section penetrated must be considered a potential source for petroleum generation, which can occur only with additional burial.

Projection of the maturation profile to the minimum oil and wet gas maturities $\left(0.6 \%\right.$ and $\left.0.8 \% \mathrm{R}_{\mathrm{O}}\right)$ indicates that these levels should occur at approximately 1870 and 2310 meters depth. Projection of the maturation profile to $0.2 \% \mathrm{R}_{\mathrm{o}}$ (maturity of first-formed vitrinite, i.e., no thermal effects) indicates that there has been essentially no erosion of the post-Cretaceous part of the section and that about 250 meters of lost section is represented by the Early Cretaceous-Miocene unconformity (Dow, 1977).

\section{Site 398}

\section{Organic and Carbonate Content}

Organic carbon contents (Table 1) are variable, even in similarly colored samples. Generally, the darker gray and black samples are higher. Greenish samples typically are lower in organic carbon, which may indicate a more oxidizing environment of deposition. The darker gray or black, more organic-rich samples may indicate a more restricted, reducing depositional environment. The Tertiary and some Cretaceous samples are calcareous and the samples from the middle and early Albian and most of the Aptian are very low in carbonate. The Tertiary samples are very low in organic carbon and considered to be nonsource in quality $(<0.4$ weight $\%$ ). Virtually all of the Cretaceous samples are rated marginal to good ( 0.3 to 1.8 weight $\%$ organic carbon), with two samples (exceeding 1.6 weight \%) rated as very good in source quality. Because the samples were selected for their dark color, they may contain more organic carbon than the section as a whole.

\section{Organic Extract}

Organic extract data are shown on Tables 2 and 3 , and gas chromatograms of the total saturate fractions for the extracted samples are shown on Figures 2 and 5. Extract to organic carbon ratios (Table 3 ) of the Tertiary and Cretaceous samples are uniformly very low, generally less than 0.02 , indicating essentially no generation of extractable organic material. Extracts from the samples are low in saturates, indicating the absence of petroleum-like extractable organics; the high NSO and asphaltene fractions indicate relative thermal immaturity. Thermal immaturity is also suggested by the odd carbon predominance (high CPIs) of the saturates as shown on Table 3.

\section{Kerogen Type}

Kerogen in the Tertiary samples is comprised of predominantly humic organic matter. Albian samples contain kerogen with predominantly amorphous organic matter and only small amounts of humic material. There is progressively less amorphous organic matter in Albian and older samples, with the oldest sediments having only small amounts (Table 3). Kerogen from the Albian section is generally an oil- 

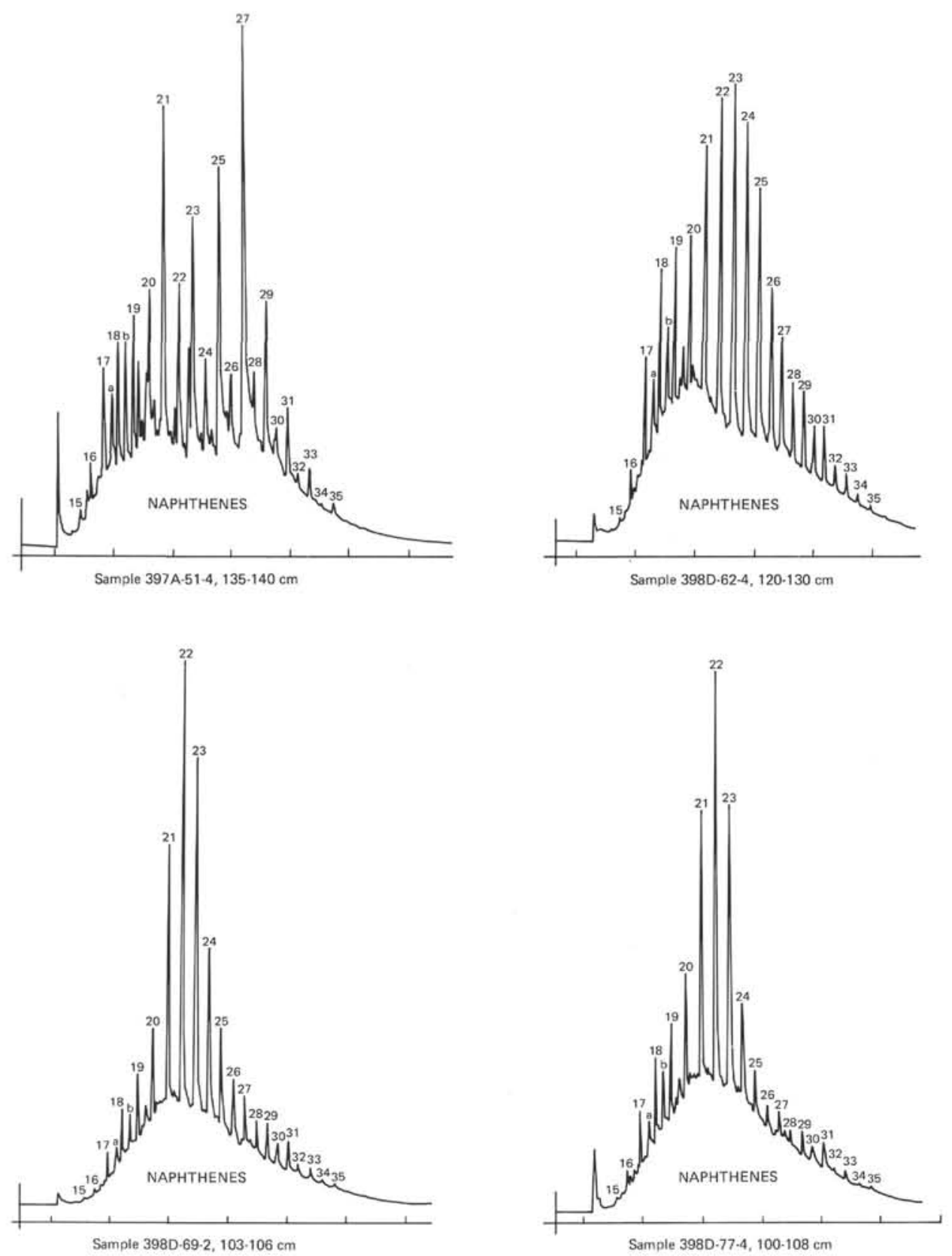

Figure 2. Gas chromatograms of the total saturate (alkane) fraction of the extractable organic matter from samples from Sites 397 and 398. (Analysis by GeoChem, Inc.)

generating type and both younger and older intervals contain gas-generating types of kerogen (Table 3 ). The continuous increase in the proportion of amorphous matter in the Cretaceous section may indicate either a progressively more-reducing depositional environment (thus preserving a greater proportion of the marine organic matter), or a decrease in the influx of terrestrial components (thereby increasing the relative proportion of amorphous matter). The absence of progressively increasing organic carbon contents suggests the latter may be the most likely possibility.

\section{Kerogen Maturity}

Maturity of the samples determined by vitrinite reflectance, $R_{o}$ average (Dow, 1977, 1978a, b) is shown on Table 4. The maturation profile (Figure 6) shows that the entire sampled section is immature and that significant oil generation has not taken place. The entire section penetrated contains potential oil and gas source beds which could yield oil and gas only with additional burial. The Cretaceous samples also contain abundant recycled humic organic matter, particles 
TABLE 4

Vitrinite Reflectance

\begin{tabular}{|c|c|c|c|c|}
\hline \multirow{2}{*}{$\begin{array}{c}\text { Sample } \\
\text { (Interval in cm) }\end{array}$} & \multirow{2}{*}{$\frac{\text { Primary }}{\text { Maturity }-\mathrm{R}_{\mathrm{o}} \%}$} & \multicolumn{3}{|c|}{ Recycled Maturity $-\mathrm{R}_{\mathrm{o}} \%$} \\
\hline & & Group $R_{1}$ & Group $R_{2}$ & Group $\mathrm{R}_{3}$ \\
\hline \multicolumn{5}{|l|}{ Leg 47A } \\
\hline $397-95-4,125-135$ & 0.34 & - & - & - \\
\hline $397 \mathrm{~A}-12-2,0-20$ & 0.33 & - & - & - \\
\hline $397 \mathrm{~A}-16-4,25-30$ & 0.36 & - & - & - \\
\hline $397 \mathrm{~A}-23-4,10-20$ & 0.38 & - & - & - \\
\hline $397 \mathrm{~A}-51-4,135-140$ & 0.50 & - & - & - \\
\hline \multicolumn{5}{|l|}{$\operatorname{Leg} 47 \mathrm{~B}$} \\
\hline 398D-12-3, 120-135 & - & - & - & 1.11 \\
\hline $398 \mathrm{D}-19-3,130-137$ & - & - & - & - \\
\hline $398 \mathrm{D}-27-2,130-140$ & - & - & - & - \\
\hline $398 \mathrm{D}-62-4,120-130$ & - & - & 0.89 & - \\
\hline $398 \mathrm{D}-65-4,100-110$ & - & - & - & 1.07 \\
\hline 398D-69-2, 103-106 & - & - & 0.91 & - \\
\hline $398 \mathrm{D}-73-4,140-145$ & - & - & - & 1.11 \\
\hline $398 \mathrm{D}-77-4,100-108$ & - & - & - & 1.14 \\
\hline $398 \mathrm{D}-80-2,100-110$ & - & - & 0.89 & - \\
\hline $398 \mathrm{D}-86-4,50-56$ & 0.42 & - & 0.95 & - \\
\hline 398D-90-5, 30-40 & - & 0.65 & 0.95 & 1.12 \\
\hline 398D-97-3, 34-50 & 0.42 & - & 1.04 & \\
\hline $398 D-103-4,40-50$ & - & - & - & 1.22 \\
\hline $398 \mathrm{D}-106-5,140-150$ & - & - & - & 1.19 \\
\hline $398 \mathrm{D}-112-2,25-50$ & - & - & - & 1.26 \\
\hline $398 \mathrm{D}-118-5,30-50$ & 0.44 & 0.71 & 0.99 & - \\
\hline 398D-122-5, 114-118 & 0.47 & - & 1.04 & 1.25 \\
\hline 398D-130-5, 113-118 & 0.48 & 0.76 & 1.06 & 1.29 \\
\hline
\end{tabular}

which have been through at least one previous cycle of burial and maturation. These samples typically exhibit three recycled populations representing multiple source regions of different maturities or, alternatively, a single source region with three sequences of distinctly different maturities.

Projection of the primary maturation profile back to $0.2 \% \mathrm{R}_{\mathrm{o}}$ (the maturity of initially formed vitrinite) sug- gests that approximately 320 meters of section has been lost to erosion, either at the Campanian-Cenomanian unconformity or at subsequent, younger, unconformities (Dow, 1977). The absence of primary vitrinite in any of the three Tertiary samples precludes determining when the missing section was lost. The average maturity of each of the recycled populations can likewise be determined by projecting to the same relative depth at which the primary profile intersects $0.2 \% \mathrm{R}_{\mathrm{O}}$. Thus, the three recycled populations had maturities of $0.28 \%$ $\mathrm{R}_{\mathrm{o}}$ (lignite rank), $0.6 \% \mathrm{R}_{\mathrm{o}}$ (high volatile " $\mathrm{B}$ " bituminous rank), and $0.86 \% \mathrm{R}_{\mathrm{o}}$ (high volatile " $\mathrm{A}$ " bituminous rank).

\section{ACKNOWLEDGMENTS}

We acknowledge Richard D. McIver of the Exxon Production Research Company and John W. Kendrick of the Shell Development Company for reviewing this manuscript and their thoughtful suggestions. We would also like to acknowledge The Superior Oil Company for its cooperation in the participation in the DSDP program.

\section{REFERENCES}

Dow, W.G., 1977. Kerogen analysis and geological interpretations, Journal of Geochem. Explor., v. 7, p. 79-99. , 1978a. Contact metamorphism of kerogen in sediments from Leg 41: Cape Verde Rise and Basin. In Lancelot, Y., Seibold, E., et al., Initial Reports of the Deep Sea Drilling Project, v. 41: Washington (U.S. Government Printing Office), p. 821-824. 1978b. Geochemical analysis of samples from Holes 391A and 391C, Leg 44: Blake-Bahama Basin. In Benson, W. E., Sheridan, R. E., et al., Initial Feports of the Deep Sea Drilling Project, v. 44: Washington (U.S. Government Printing Office), p. 625-634. 


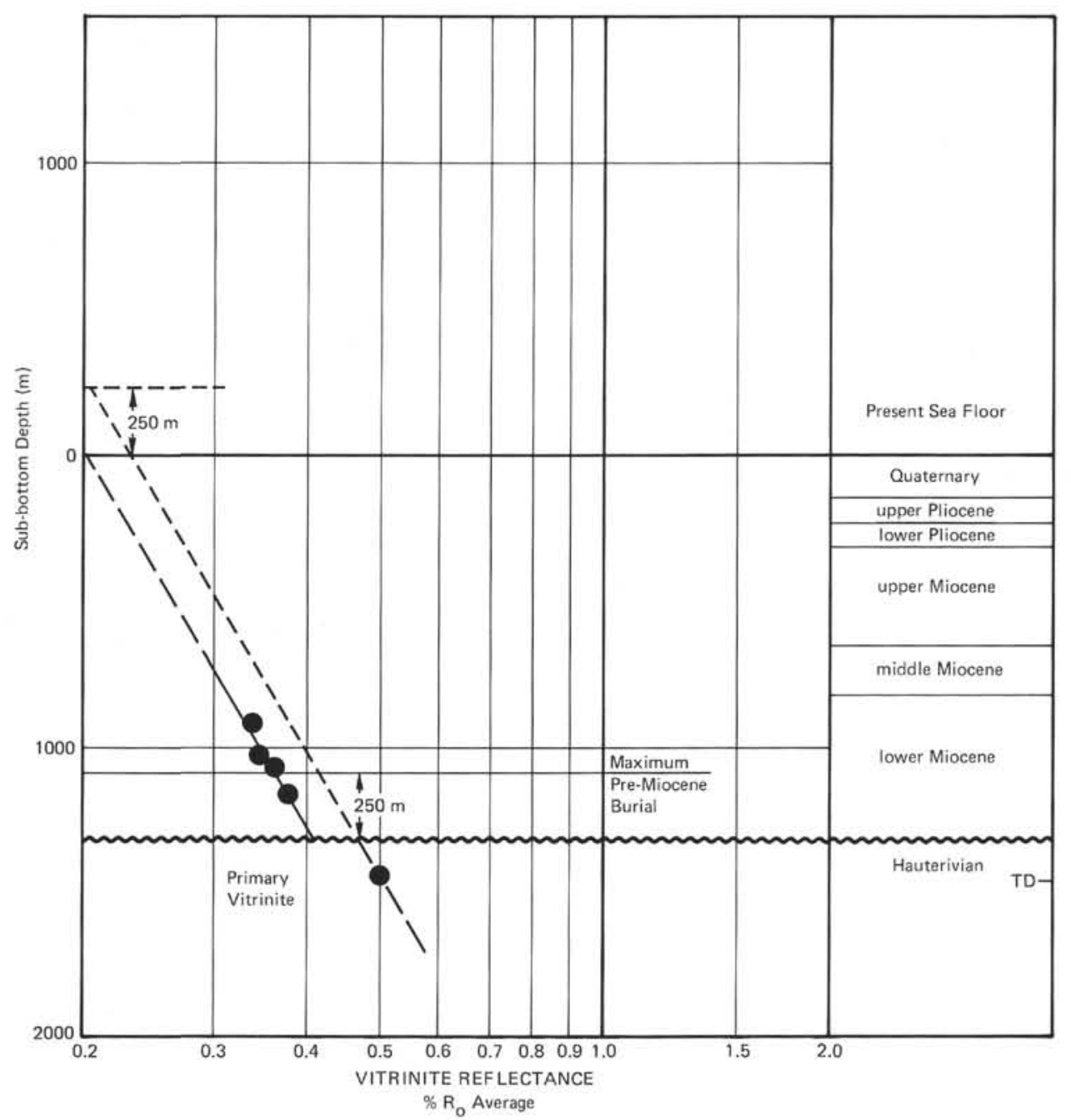

Figure 3. Kerogen maturation profile showing primary vitrinite maturity and projected thickness of the lost section at Site 397. 


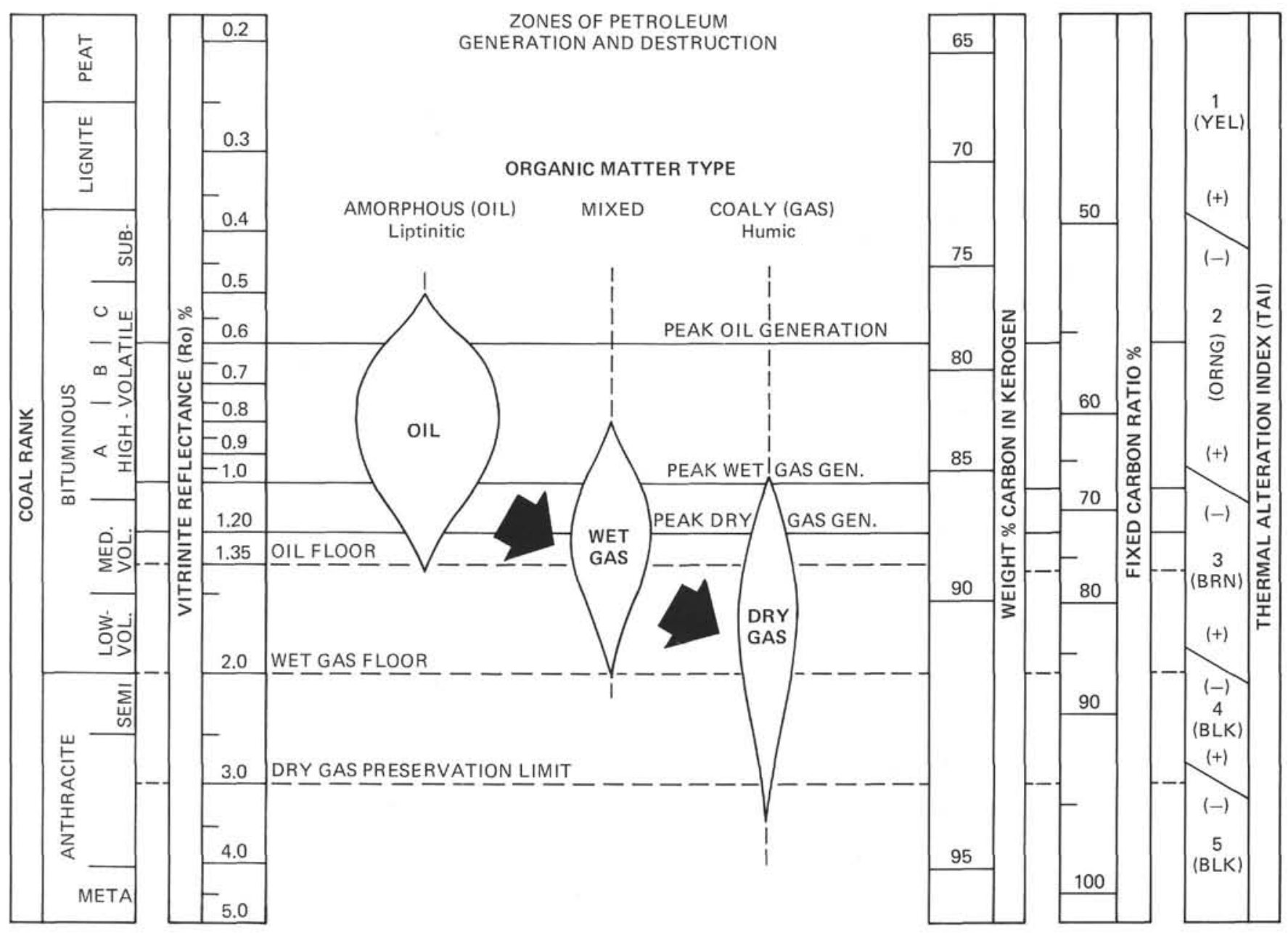

Figure 4. Correlation of the coal rank scale with various maturation indexes to the zones of petroleum generation and destruction. 

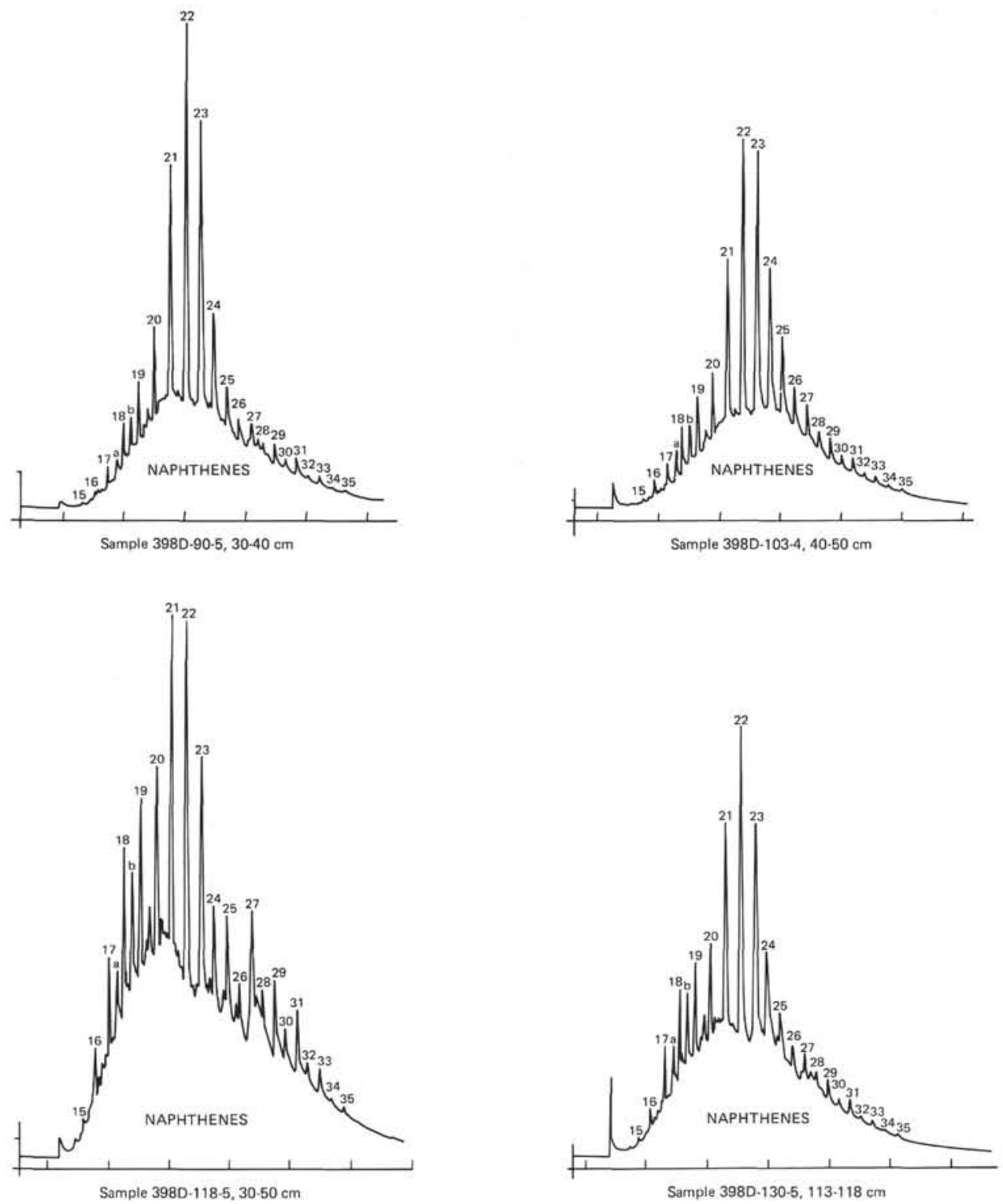

Figure 5. Gas chromatograms of the total saturate (alkane) fraction of the extractable organic matter from Site 398 samples. (Analysis by GeoChem, Inc.) 


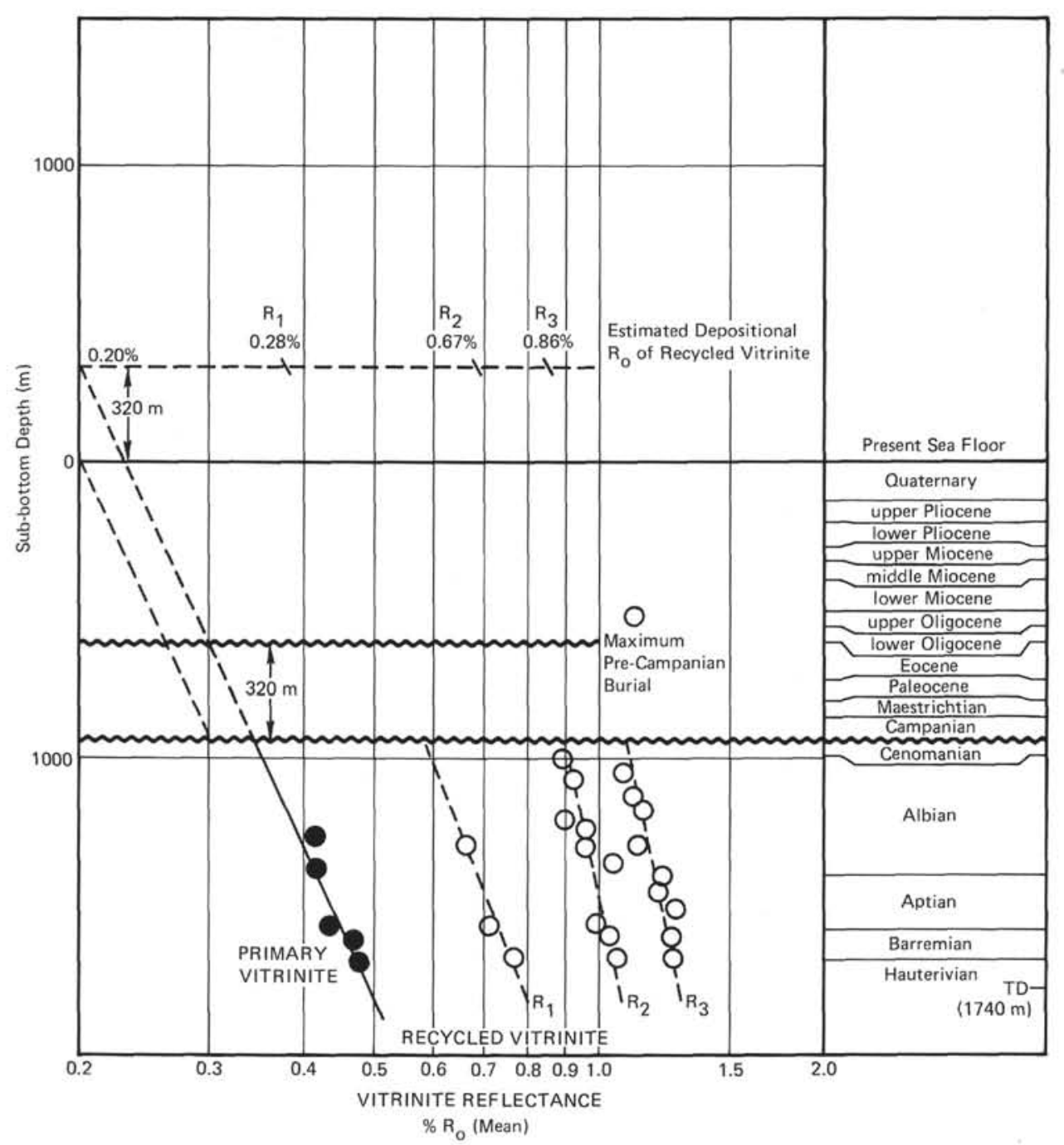

Figure 6. Kerogen maturation profile showing primary vitrinite maturity, recycled vitrinite, and projected thickness of the lost section at Site 398. Also shown are the estimated reflectances of the recycled vitrinite groups at the time of deposition. 